\title{
PENGARUH TANGGUNG JAWAB PROFESI, KOMITMEN MENGAJAR, MOTIVASI, DAN KEPUASAN KERJA TERHADAP EFEKTIVITAS KINERJA GURU
}

\author{
MARDHIAH \\ Fakultas Tarbiyah dan Keguruan, Universitas Islam Negeri Alauddin Makassar \\ Email: mardhiah.hasan@uin-alauddin.ac.id
}

(Article History)

Received May 24, 2021; Revised June 13, 2021; Accepted June 15, 2021

\begin{abstract}
The Influence of Professional Responsibility, Teaching Commitment, Motivation, and Job Satisfaction on Teacher Performance Effectiveness

This research was conducted to determine the effectiveness of teacher performance in Makassar City based on the factors that influence it, namely; professional responsibility, teaching commitment, motivation, and job satisfaction. This study uses primary data through distributing questionnaires in the form of Google Form to 304 teachers as a sample of all 1259 Madrasah Tsanawiyah teachers in Makassar City. Distribution of questionnaires was carried out in April 2021. Data were analyzed using multiple linear regression analysis. The results of this study indicate that: (1) professional responsibility has a positive and significant direct effect on the effectiveness of teacher performance; (2) Commitment to teaching has a positive and significant direct effect on the effectiveness of teacher performance; (3) Motivation has a positive and significant direct effect on the effectiveness of teacher performance; (4) Job satisfaction has a positive and significant direct effect on the effectiveness of teacher performance; (5) Professional responsibility, teaching commitment, motivation and job satisfaction together have a significant influence on the effectiveness of teacher performance. The research results can be used as input for school principals and policy makers in an effort to improve teacher performance by paying attention to, shaping and increasing professional responsibility, teaching commitment, motivation and job satisfaction of teachers, especially teachers.
\end{abstract}

Keywords: Professional Responsibility, Teaching Commitment, Motivation, Work Satisfaction, Teacher Performance

Abstrak: Pengaruh Tanggung Jawab Profesi, Komitmen Mengajar, Motivasi, dan Kepuasan Kerja Terhadap Efektivitas Kinerja Guru

Penelitian ini dilakukan untuk mengetahui efektivitas kinerja guru Madrasah

Tsanawiyah di Kota Makassar berdasarkan faktor-faktor yang mempengaruhinya, yaitu; tanggung jawab profesi, komitmen mengajar, motivasi, dan kepuasan kerja. Penelitian ini menggunakan data primer melalui penyebaran angket dalam bentuk Google Form kepada 304 orang guru sebagai sampel dari seluruh jumlah guru Madrasah Tsanawiyah di Kota Makassar sebanyak 1.259 orang. Penyebaran angket dilakukan pada April 2021. Data dianalisis dengan menggunakan analisis regresi linear berganda. Hasil penelitian ini menunjukkan bahwa: (1) Tanggung jawab profesi 
mempunyai pengaruh langsung positif dan signifikan terhadap efektivitas kinerja guru; (2) Komitmen mengajar mempunyai pengaruh langsung positif dan signifikan terhadap efektivitas kinerja guru; (3) Motivasi mempunyai pengaruh langsung positif dan signifikan terhadap efektivitas kinerja guru; (4) Kepuasan kerja mempunyai pengaruh langsung positif dan signifikan terhadap efektivitas kinerja guru; (5) Tanggung jawab profesi, komitmen mengajar, motivasi dan kepuasan kerja secara bersama-sama mempunyai pengaruh signifikan terhadap efektivitas kinerja guru. Hasil penelitian dapat digunakan sebagai masukan bagi kepala sekolah dan pengambil kebijakan dalam upaya meningkatkan kinerja guru dengan memerhatikan, membentuk dan meningkatkan tanggung jawab profesi, komitmen mengajar, motivasi, serta kepuasan kerja para guru khususnya guru Madrasah Tsanawiyah.

Kata Kunci: Tanggung Jawab Profesi, Komitmen Mengajar, Motivasi, Kepuasan Kerja, Kinerja Guru

\section{PENDAHULUAN}

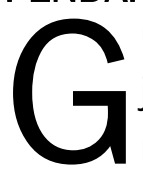
uru atau pendidik dalam pendidikan Islam adalah orang yang bertanggung jawab terhadap perkembangan peserta didik dengan upaya mengembangkan seluruh potensi peserta didik, baik potensi afektif, kognitif, maupun psikomotorik (Bukhari, 2010: 83). Mengutip perkataan dari Imam al-Ghazali, "Tugas seorang pendidik yang utama adalah menyempurnakan, membersihkan, menyucikan, dan membimbing hati manusia untuk mendekatkan diri (taqarrub) kepada Allah swt". Lebih lanjut dijelaskan menurut Imam al-Ghazali bahwa guru/pendidik yang dapat diserahi tugas mengajar adalah guru yang selain cerdas dan sempurna akalnya, juga guru yang baik akhlak dan kuat fisiknya.

Pendapat Danial, et al. (2019) yang dikutip sebagai berikut “Kinerja guru merupakan salah satu faktor yang tolok ukur keberhasilan pendidikan di madrasah karena guru merupakan salah seorang pelaksana pendidikan yang diperlukan". Akan tetapi, kinerja yang dihasilkan oleh guru akan bergantung pada motivasi kerja yang mereka miliki. Hal tersebut sebagaimana dikemukakan oleh Rahman dan Husain (2020: 93), “Motivasi kerja seseorang merupakan salah satu faktor yang turut menentukan kinerja seseorang. Besar kecilnya pengaruh motivasi pada kinerja seseorang tergantung pada seberapa banyak intensitas motivasi yang diberikan kepadanya".

Kepemilikan kualifikasi kompetensi menjadi modal bagi seorang pendidik dalam mengajar, mendidik, mengarahkan, membentuk dan mempersiapkan anak didiknya dalam suatu proses pembelajaran dan pendidikan yang efektif sehingga menjadikannya sosok dewasa yang bertakwa, mandiri, mampu menghadapi kehidupan masa depan dengan sangat baik, selamat dan bahagia dunia akhirat. Hal ini sejalan dengan hasil penelitian Tafqihan dan Suryanto (2014) yang menyimpulkan bahwa: terdapat pengaruh positif kompetensi terhadap komitmen professional sebesar 15,9\%, terdapat pengaruh kompetensi terhadap kinerja 
sebesar 63,6\%, terdapat pengaruh komitmen terhadap kinerja sebesar15,9\%, dan terdapat pengaruh antara komitmen profesional terhadap kepuasan kerja. Hasil penelitian ini sesuai dengan teori yang dikemukakan oleh Glickman dalam Ibrahim, "Seseorang akan bekerja professional bila orang tersebut memiliki kemampuan tinggi (high level of abstract) dan komitmen kerja tinggi (high level commitment)".

Zangaro (2001: 14) mengatakan bahwa "Komitmen sebagai tindakan atau janji untuk memenuhi kewajiban kepada seseorang atau sesuatu di masa datang." Dengan demikian, komitmen merupakan tindakan seseorang yang berusaha sangat keras untuk melakukan kewajiban pada seseorang atau mendukung sesuatu di masa depan. Komitmen guru tercermin dalam perilakunya pada pelaksanaan tugas pokoknya sebagai guru dan keterlibatan pada kegiatan sekolah.

Pada saat ini, masih terdapat persepsi yang menyudutkan profesi dan kinerja guru, Usman (2005) mengatakan di antaranya, yaitu : (1) Siapa pun dapat menjadi guru; (2) Banyak guru yang masih minder dengan profesinya; (3) Wibawa guru semakin merosot. Salah satu hasil penelitian yang mendukung hal tersebut adalah kesimpulan dari disertasi Sulaiman Saat pada guru Madrasah Tsanawiyah di Kabupaten Enrekang bahwa pemberian sertifikasi tidak memberikan berpengaruh dalam upaya meningkatkan berbagai kompetensi guru, seperti kompetensi profesional dan kompetensi pedagogik (Sukamto, 2016).

Penilaian kinerja adalah sebuah titik awal bagi diskusi serta diagnosis lebih lanjut. Dalam hal ini, dikutip pernyataan dari Boyd (2002) sebagai berikut:

“Evaluasi kinerja guru didesain untuk melayani dua tujuan, yaitu: (1) untuk mengukur kompetensi guru dan (2) mendukung pengembangan professional. Dengan demikian, perlu diadakan tinjauan kembali terhadap kinerja guru pada Madrasah Tsanawiyah di Kota Makassar karena yang sebagai salah satu sarana diagnosis awal dalam pengembangan dan peningkatan kinerja guru."

Berdasarkan uraian di atas, kajian ini dilakukan untuk mengetahui efektivitas kinerja guru MTs di Kota Makassar berdasarkan faktor-faktor yang memengaruhinya, yaitu tanggung jawab profesi, komitmen mengajar, motivasi, dan kepuasan kerja. Keempat faktor tersebut dianggap berpengaruh terhadap efektivitas kinerja guru pada Madrasah Tsanawiyah di Kota Makassar.

\section{METODE PENELITIAN}

Penelitian ini adalah penelitian yang menggunakan pendekatan kuantitatif. Penelitian kuantitatif digunakan dengan tujuan untuk menganalisis hubungan antar variabel, menguji teori, serta memberi kesimpulan generalisasi yang memiliki nilai prediktif. Kajian penelitian ini akan menganalisis pengaruh tanggung jawab profesi, komitmen mengajar, motivasi dan kepuasan kerja terhadap kinerja guru pada Madrasah Tsanawiyah di Kota Makassar. Lokasi penelitian ini di Madrasah Tsanawiyah Kota Makassar. Waktu penelitian berlangsung pada Maret- April 2021.Responden dalam penelitian ini sebanyak 304 orang guru yang diambil dari 
1.259 guru pada Madrasah Tsanawiyah Kota Makassar. Teknik pengumpulan data yang dipakai pada penelitian ini yaitu angket, wawancara, dan dokumentasi. Adapun data yang diperoleh, dianalisis dengan menggunakan analisis deskriptif, regresi sederhana dan berganda.

\section{HASIL PENELITIAN DAN PEMBAHASAN}

Penelitian ini dilakukan pada Madrasah Tsanawiyah di Kota Makassar. Berdasarkan hasil dokumentasi yang diperoleh, data jumlah Madrasah Tsanawiyah di Kota Makassar sebanyak 49 yang terdiri dari 2 Madrasah Tsanawiyah yang berstatus negeri dan 47 swasta. Adapun akreditasi madrasah ini terdiri 3 terakreditasi A, selebihnya terakreditasi B dan masih memiliki izin operasional. Adapun guru yang sudah tersertifikasi berjumlah 353 orang dan guru yang berstatus PNS sebanyak 191 orang.

Deskripsi Tanggung Jawab Profesi, Komitmen Mengajar, Motivasi, Kepuasan Kerja, dan Efektivitas Kinerja Guru

Data yang diperoleh pada Madrasah Tsanawiyah di Kota Makassar berdasarkan hasil pengisian angket dari 304 orang guru terkait tanggung jawab profesi, komitmen mengajar, motivasi, kepuasan kerja, dan efektivitas kinerja guru, dapat dianalisis secara deskriptif melalui statistik deskriptif dengan output pada Tabel 1.

Tabel 1. Hasil Analisis Statistik Deskriptif

\begin{tabular}{|c|c|c|c|c|c|c|}
\hline & & $\begin{array}{c}\text { Tanggung } \\
\text { Jawab } \\
\text { Profesi }\end{array}$ & $\begin{array}{l}\text { Komitmen } \\
\text { Mengajar }\end{array}$ & Motivasi & $\begin{array}{c}\text { Kepuasan } \\
\text { Kerja }\end{array}$ & $\begin{array}{c}\text { Efektivitas } \\
\text { Kinerja }\end{array}$ \\
\hline \multirow[t]{2}{*}{$N$} & Valid & 304 & 304 & 304 & 304 & 304 \\
\hline & Missing & 0 & 0 & 0 & 0 & 0 \\
\hline \multicolumn{2}{|c|}{ Mean } & 66,0592 & 79,9276 & 79,3783 & 87,1283 & 103,0428 \\
\hline \multicolumn{2}{|c|}{ Median } & 68,0000 & 82,0000 & 82,0000 & 89,0000 & 107,0000 \\
\hline \multicolumn{2}{|c|}{ Mode } & 55,00 & 90,00 & 83,00 & 99,00 & 110,00 \\
\hline \multicolumn{2}{|c|}{ Std. Deviation } & 9,20377 & 10,94818 & 11,50742 & 12,48788 & 15,25649 \\
\hline \multicolumn{2}{|c|}{ Variance } & 84,709 & 119,863 & 132,421 & 155,947 & 232,761 \\
\hline \multicolumn{2}{|c|}{ Skewness } &,- 724 &,- 816 &,- 937 &,- 489 &,- 958 \\
\hline \multicolumn{2}{|c|}{$\begin{array}{l}\text { Std. Error of } \\
\text { Skewness }\end{array}$} & ,140 & ,140 & ,140 & , 140 & 140 \\
\hline \multicolumn{2}{|c|}{ Kutosis } & ,389 & 692 & ,609 & ,341 & ,711 \\
\hline \multicolumn{2}{|c|}{ Std. Error of Kurtosis } & ,279 & ,279 & ,279 & ,279 & ,279 \\
\hline \multicolumn{2}{|c|}{ Range } & 46,00 & 54,00 & 55,00 & 66,00 & 73,00 \\
\hline \multicolumn{2}{|c|}{ Minimum } & 41,00 & 50,00 & 48,00 & 52,00 & 61,00 \\
\hline \multicolumn{2}{|c|}{ Maximum } & 87,00 & 104,00 & 103,00 & 118,00 & 134,00 \\
\hline
\end{tabular}

Sumber data: Hasil analisis data, 2021 
Hasil analisis statistik deskriptif pada Tabel 1 tentang tanggung jawab profesi, komitmen mengajar, motivasi, kepuasan kerja, dan kinerja guru pada Madrasah Tsanawiyah, selanjutnya dideskripsikan lebih lanjut sebagai berikut:

\section{Deskripsi Tanggung Jawab Profesi Guru pada Madrasah Tsanawiyah di Kota Makassar}

Tanggung jawab guru merupakan perilaku yang merupakan cerminan dari pelaksanaan kewajiban guru. Tanggung jawab profesi diwujudkan melalui kepemilikan kompetensi yang dipunyai oleh guru dalam rangka pelaksanaan tugas dan kewajiban keguruannya sehingga dapat mencapai tujuan dengan maksimal.

Hasil analisis statistik deskriptif (Tabel 1) untuk data tanggung jawab profesi (25 butir angket) menunjukkan bahwa skor perolehan tertinggi sebesar 87 dari skor tertinggi ideal sebesar 125 (25 x 5). Skor peroleh terendah sebesar 41 dari skor terendah ideal sebesar 25 (25 x 1). Nilai Mean (rata-rata) sebesar 66,0592, Median sebesar 68,0000 dan Modus sebesar 55,00. Nilai Median yang lebih besar dari nilai Mean menunjukkan bahwa kebanyakan responden yang memiliki skor tinggi melebihi nilai Mean. Hasil ini diperkuat oleh nilai Skewness (kemencengan) sebesar -0,724. Nilai skewness adalah negatif (menceng ke kanan) menujukkan bahwa responden yang memperoleh skor tinggi lebih banyak dibandingkan dengan yang memiliki skor rendah. Nilai skewness tersebut masih tergolong normal (tidak terlalu menceng kekanan) karena masih dalam interval antara -3 dan +3 . Selain itu, nilai Kurtosis (kecembungan) sebesar 0,389 adalah positif yang juga menunjukkan bahwa responden yang memiliki skor tinggi lebih banyak dari responden yang memiliki skor rendah. Nilai Kurtosis tersebut masih dalam batas normal dan termasuk kategori platikurtik (nilai kurtosis kurang dari 3). Nilai Variance sebesar 84,709 yang berpadanan dengan nilai standar deviasi (simpangan baku) sebesar 9,20377 yang menunjukkan bahwa penyebaran data sangat beragam.

Nilai variabel tanggung jawab profesi guru pada Madrasah Tsanawiyah di Kota Makassar berdasarkan hasil analisis statistik deskriptif dapat dibuatkan kategori data skor perolehan seperti terlihat pada Tabel 2.

Tabel 2. Kategori Data Skor Perolehan Angket Tanggung Jawab Profesi

\begin{tabular}{l|l|r|r|r|r}
\hline \multicolumn{2}{c|}{ Categories } & Frequency & Percent & Valid Percent & $\begin{array}{c}\text { Cumulative } \\
\text { Percent }\end{array}$ \\
\hline Valid & Sangat Rendah & 26 & 8,6 & 8,6 & 8,6 \\
& Rendah & 45 & 14,8 & 14,8 & 23,4 \\
& Sedang & 98 & 32,2 & 32,2 & 55,6 \\
& Tinggi & 111 & 36,5 & 36,5 & 92,1 \\
& Sangat Tinggi & 24 & 7,9 & 7,9 & 100,0 \\
& Total & 304 & 100,0 & 100,0 & \\
\hline
\end{tabular}

Sumber: Hasil analisis data, 2021 
Merujuk pada Tabel 2, dapat diketahui responden yang mempunyai skor tinggi lebih banyak jika diperbandingkan dengan yang mendapatkan skor rendah. Oleh karena itu, dapat dinyatakan bahwa tanggung jawab profesi yang dimiliki oleh guru pada Madrasah Tsanawiyah di Kota Makassar tergolong tinggi.

Deskripsi Komitmen Mengajar Guru pada Madrasah Tsanawiyah di Kota Makassar

Komitmen mengajar guru merupakan upaya maksimal seorang guru dalam pelaksanaan berbagai tugas serta tanggung jawab secara optimal. Komitmen mengajar guru dapat dilihat dari komitmen dalam merancang pembelajaran, komitmen dalam pengelolaan pembelajaran, komitmen mengarahkan, pembelajaran, komitmen sebagai pelaksana kurikulum, komitmen sebagai evaluator, dan komitmen terhadap peserta didik.

Hasil analisis statistik deskriptif (lihat Tabel 1) untuk data komitmen mengajar (30 butir angket) menunjukkan bahwa skor perolehan tertinggi sebesar 104,00 dari skor tertinggi ideal sebesar 150 (30 x 5). Skor peroleh terendah sebesar 50,00 dari skor terendah ideal sebesar 30 (30 x 1). Nilai mean (rata-rata) sebesar 79,9276, median sebesar 82,0000 dan modus sebesar 90,00. Nilai median yang lebih besar dari nilai mean menunjukkan bahwa kebanyakan responden yang memiliki skor tinggi melebihi nilai mean. Hasil ini diperkuat oleh nilai skewness (kemencengan) sebesar -0,816. Nilai skewness adalah negatif (menceng ke kanan) menunjukkan bahwa responden yang memperoleh skor tinggi lebih banyak dibandingkan dengan yang memiliki skor rendah. Nilai skewness tersebut masih tergolong normal (tidak terlalu menceng ke kanan) karena masih dalam interval antara -3 dan +3 . Selain itu, nilai kurtosis (kecembungan) sebesar 0,692 adalah positif yang juga menunjukkan bahwa responden yang memiliki skor tinggi lebih banyak dari responden yang memiliki skor rendah. Nilai kurtosis tersebut masih dalam batas normal dan termasuk kategori platikurtik (nilai kurtosis kurang dari 3). Nilai variance sebesar 119,863 yang berpadanan dengan nilai standar deviasi (simpangan baku) sebesar 10,94818 yang menunjukkan bahwa penyebaran data sangat beragam.

Nilai variabel komitmen mengajar guru pada Madrasah Tsanawiyah di Kota Makassar berdasarkan hasil analisis statistik deskriptif dapat dibuatkan kategori data skor perolehan seperti terlihat pada Tabel 3.

Tabel 3. Kategori Data Skor Perolehan Angket Komitmen Mengajar

\begin{tabular}{l|r|r|r|r}
\hline Categories & Frequency & Percent & Valid Percent & Cumulative Percent \\
\hline Valid Sangat Rendah & 27 & 8,9 & 8,9 & 8,9 \\
Rendah & 44 & 14,5 & 14,5 & 23,4 \\
Sedang & 86 & 28,3 & 28,3 & 51,6 \\
Tinggi & 123 & 40,5 & 40,5 & 92,1 \\
Sangat Tinggi & 24 & 7,9 & 7,9 & 100,0 \\
\hline Total & 304 & 100,0 & 100,0 & \\
\hline
\end{tabular}

Sumber: Hasil analisis data, 2021 
Merujuk pada Tabel 3, dapat diketahui responden yang mempunyai skor tinggi lebih banyak jika diperbandingkan dengan yang mendapatkan skor rendah. Oleh karena itu, komitmen mengajar yang dipunyai oleh guru pada Madrasah Tsanawiyah di Kota Makassar dapat dinyatakan tergolong tinggi.

\section{Deskripsi Motivasi Kerja Guru pada Madrasah Tsanawiyah di Kota Makassar}

Motivasi merupakan suatu dorongan, keinginan atau minat yang berada dalam diri, untuk menggapai suatu harapan, cita-citra serta tujuan seseorang. Adanya motivasi memberikan kekuatan seorang guru untuk berusaha dengan maksimal untuk melaksanakan tugas dan tanggung jawabnya. Motivasi dalam kajian ini dilihat dari keinginan untuk berhasil, keinginan mengembangkan diri, adanya rasa aman, berani menanggung resiko, dan keinginan bekerja sama.

Hasil analisis statistik deskriptif (lihat Tabel 1) untuk data motivasi (30 butir angket) menunjukkan bahwa skor perolehan tertinggi sebesar 103,00 dari skor tertinggi ideal sebesar 150 (30 x 5). Skor peroleh terendah sebesar 48,00 dari skor terendah ideal sebesar 30 (30 x 1). Nilai Mean (rata-rata) sebesar 79,3783, Median sebesar 82,0000 dan Modus sebesar 83,00. Nilai Median yang lebih besar dari nilai mean menunjukkan bahwa kebanyakan responden yang memiliki skor tinggi melebihi nilai Mean.

Hasil ini diperkuat oleh nilai skewness (kemencengan) sebesar -0,937. Nilai skewness adalah negatif (menceng ke kanan) menujukkan bahwa responden yang memperoleh skor tinggi lebih banyak dibandingkan dengan yang memiliki skor rendah. Nilai skewness tersebut masih tergolong normal (tidak terlalu menceng ke kanan) karena masih dalam interval antara -3 dan +3 . Selain itu, nilai kurtosis (kecembungan) sebesar 0,609 adalah positif yang juga menunjukkan bahwa responden yang memiliki skor tinggi lebih banyak dari responden yang memiliki skor rendah. Nilai kurtosis tersebut masih dalam batas normal dan termasuk kategori platikurtik (nilai kurtosis kurang dari 3). Nilai variance sebesar 132,421 yang berpadanan dengan nilai standar deviasi (simpangan baku) sebesar 11,50742 yang menunjukkan bahwa penyebaran data sangat beragam.

Nilai variabel motivasi kerja guru pada Madrasah Tsanawiyah di Kota Makassar berdasarkan hasil analisis statistik deskriptif dapat dibuatkan kategori data skor perolehan seperti terlihat pada Tabel 4. Merujuk pada Tabel 4, dapat diketahui responden yang mempunyai skor tinggi lebih banyak diperbandingkan dengan yang mendapatkan skor rendah. Oleh karena itu, motivasi kerja yang ada dalam diri guru pada Madrasah Tsanawiyah di Kota Makassar dapat dinyatakan tergolong tinggi. 
Tabel 4. Kategori Data Skor Perolehan Angket Motivasi

\begin{tabular}{ll|r|r|r|r}
\hline \multicolumn{1}{c|}{ Categories } & Frequency & Percent & Valid Percent & $\begin{array}{c}\text { Cumulative } \\
\text { Percent }\end{array}$ \\
\hline Valid & Sangat Rendah & 26 & 8,6 & 8,6 & 8,6 \\
& 45 & 14,8 & 14,8 & 23,4 \\
Rendah & 63 & 20,7 & 20,7 & 44,1 \\
Sedang & 120 & 39,5 & 39,5 & 83,6 \\
Tinggi & 50 & 16,4 & 16,4 & 100,0 \\
Sangat Tinggi & 304 & 100,0 & 100,0 & \\
Total & &
\end{tabular}

Sumber: Hasil analisis data, 2021

\section{Deskripsi Kepuasan Kerja Guru pada Madrasah Tsanawiyah di Kota Makassar}

Kepuasan kerja adalah gambaran mengenai perasaan seseorang terkait pekerjaan serta kondisi lingkungan kerjanya. Adapun yang dimaksud kepuasan kerja adalah skor hasil pengukuran berbagai indikator kepuasan kerja yang ada seperti aneka variasi kebutuhan, yakni kebutuhan: fisiologis, keselamatan, cinta, harga diri, dan aktualisasi diri.

Hasil analisis statistik deskriptif (Lihat Tabel 1) untuk data kepuasan kerja (33 butir angket) menunjukkan bahwa skor perolehan tertinggi sebesar 118,00 dari skor tertinggi ideal sebesar 165 (33 x 5). Skor peroleh terendah sebesar 52,00 dari skor terendah ideal sebesar 33 (33 x 1). Nilai mean (rata-rata) sebesar 87,1283, median sebesar 89,0000 dan modus sebesar 89,00. Nilai Median yang lebih besar dari nilai Mean menunjukkan bahwa kebanyakan responden yang memiliki skor tinggi melebihi nilai Mean. Hasil ini diperkuat oleh nilai skewness (kemencengan) sebesar -0,489. Nilai skewness adalah negatif (menceng ke kanan) menujukkan bahwa responden yang memperoleh skor tinggi lebih banyak dibandingkan dengan yang memiliki skor rendah. Nilai skewness tersebut masih tergolong normal (tidak terlalu menceng ke kanan) karena masih dalam interval antara -3 dan +3 . Selain itu, nilai kurtosis (kecembungan) sebesar 0,341 adalah positif yang juga menunjukkan bahwa responden yang memiliki skor tinggi lebih banyak dari responden yang memiliki skor rendah. Nilai kurtosis tersebut masih dalam batas normal dan termasuk kategori platikurtik (nilai kurtosis kurang dari 3). Nilai variance sebesar 155,947 yang berpadanan dengan nilai standar deviasi (simpangan baku) sebesar 12,48788 yang menunjukkan bahwa penyebaran data sangat beragam.

Nilai variabel kepuasan kerja guru pada Madrasah Tsanawiyah di Kota Makassar berdasarkan hasil analisis statistik deskriptif dapat dibuatkan kategori data skor perolehan seperti terlihat pada Tabel 5. Merujuk pada Tabel 5, dapat diketahui responden yang mempunyai skor tinggi lebih banyak jika diperbandingkan dengan yang mendapatkan skor rendah. Oleh karena itu, 
kepuasan kerja yang dipunyai oleh guru pada Madrasah Tsanawiyah di Kota Makassar dapat dinyatakan tergolong tinggi.

Tabel 5. Kategori Data Skor Perolehan Angket Kepuasan Kerja

\begin{tabular}{l|r|r|r|r}
\hline Categories & Frequency & Percent & Valid Percent & Cumulative Percent \\
\hline Valid Sangat rendah & 26 & 8,6 & 8,6 & 8,6 \\
Rendah & 45 & 14,8 & 14,8 & 23,4 \\
Sedang & 110 & 36,2 & 36,2 & 59,5 \\
Tinggi & 99 & 32,6 & 32,6 & 92,1 \\
Sangat Tinggi & 24 & 7,9 & 7,9 & 100,0 \\
Total & 304 & 100,0 & 100,0 & \\
\hline
\end{tabular}

Sumber: Hasil analisis data, 2021

\section{Deskripsi Efektivitas Kinerja Guru pada Madrasah Tsanawiyah di Kota Makassar}

Efektivitas kerja guru adalah tingkat keberhasilan guru dalam merencanakan, melaksanakan proses pembelajaran, mengevaluasi pembelajaran, sehingga terwujud tujuan pembelajaran dengan maksimal melalui penggunaan berbagai sumber daya, dana secara efektif dan efisien. Adapun aspek kinerja guru, yaitu merencanakan pembelajaran, menyajikan pembelajaran, dan mengadakan evaluasi.

Hasil analisis statistik deskriptif (lihat Tabel 1) untuk data efektivitas kinerja (39 butir angket) menunjukkan bahwa skor perolehan tertinggi sebesar 134 dari skor tertinggi ideal sebesar 195 (39 x 5). Skor peroleh terendah sebesar 61 dari skor terendah ideal sebesar 39 (39 x 1). Nilai mean (rata-rata) sebesar 103,0428, median sebesar 107,0000 dan modus sebesar 110,0000. Nilai median yang lebih besar dari nilai mean menunjukkan bahwa kebanyakan responden yang memiliki skor tinggi melebihi nilai mean. Hasil ini diperkuat oleh nilai skewness (kemencengan) sebesar -0,958. Nilai skewness adalah negatif (menceng ke kanan) menunjukkan bahwa responden yang memperoleh skor tinggi lebih banyak dibandingkan dengan yang memiliki skor rendah. Nilai skewness tersebut masih tergolong normal (tidak terlalu menceng ke kanan) karena masih dalam interval antara -3 dan +3 . Selain itu, nilai kurtosis (kecembungan) sebesar 0,711 adalah positif yang juga menunjukkan bahwa responden yang memiliki skor tinggi lebih banyak dari responden yang memiliki skor rendah. Nilai kurtosis tersebut masih dalam batas normal dan termasuk kategori platikurtik (nilai kurtosis kurang dari 3). Nilai variance sebesar 232,761 yang berpadanan dengan nilai standar deviasi (simpangan baku) sebesar 15,256492 yang menunjukkan bahwa penyebaran data sangat beragam.

Nilai variabel kepuasan kerja guru pada Madrasah Tsanawiyah di Kota Makassar berdasarkan hasil analisis statistik deskriptif dapat dibuatkan kategori data skor perolehan seperti terlihat pada Tabel 6. Merujuk pada Tabel 6, dapat diketahui responden yang mempunyai skor tinggi lebih banyak jika 
diperbandingkan dengan yang mempunyai skor rendah. Oleh karena itu, efektivitas kinerja guru Madrasah Tsanawiyah di Kota Makassar dapat dinyatakan tergolong tinggi.

Tabel 6. Kategori Data Skor Perolehan Angket Efektivitas Kinerja

\begin{tabular}{c|r|r|r|r}
\hline Categories & Frequency & Percent & Valid Percent & Cumulative Percent \\
\hline Valid Sangat rendah & 26 & 8,6 & 8,6 & 8,6 \\
Rendah & 44 & 14,5 & 14,5 & 23,0 \\
sedang & 64 & 21,1 & 21,1 & 44,1 \\
tinggi & 121 & 39,8 & 39,8 & 83,9 \\
Sangat tinggi & 49 & 16,1 & 16,1 & 100,0 \\
Total & 304 & 100,0 & 100,0 & \\
\hline
\end{tabular}

Sumber: Hasil analisis data, 2021

Pengaruh Tanggung Jawab Profesi terhadap Efektivitas Kinerja Guru pada Madrasah Tsanawiyah di Kota Makassar

Hasil analisis data dengan menggunakan analisis regresi linear sederhana tentang pengaruh tanggung jawab profesi terhadap efektivitas kinerja guru pada Madrasah Tsanawiyah di Kota Makassar terlihat pada Tabel 7.

Tabel 7. Persamaan Regresi Pengaruh Tanggung Jawab Profesi terhadap Efektivitas Kinerja Guru

\begin{tabular}{|c|c|c|c|c|c|}
\hline & \multicolumn{2}{|c|}{ Coefficients } & \multirow[b]{2}{*}{$\begin{array}{c}\text { Standardized } \\
\text { Coefficients }\end{array}$} & \multirow[b]{3}{*}{$t$} & \multirow[b]{3}{*}{ Sig. } \\
\hline \multirow[b]{2}{*}{ Model } & \multicolumn{2}{|c|}{$\begin{array}{l}\text { Unstandardized } \\
\text { Coefficients }\end{array}$} & & & \\
\hline & $B$ & Std. Error & Beta & & \\
\hline (Constant) & 3,926 & 1,360 & & 2,886 &, 004 \\
\hline $\begin{array}{l}\text { Tanggung Jawab } \\
\text { Profesi }\end{array}$ & & 020 & 977 & 79,386 & ,000 \\
\hline
\end{tabular}

Sumber: Hasil analisis data, 2021

Tabel 7 menunjukkan bahwa koefisien regresi diperoleh regresi b sebesar 1,619 dan konstanta a sebesar 3,926. Dengan demikian, bentuk hubungan antara kedua variabel tersebut dapat dinyatakan oleh persamaan regresi: $\hat{Y}=3,926+$ 1,619 X. Berdasarkan perhitungan yang dilakukan, ditemukan bahwa efektivitas kinerja guru tanpa tanggung jawab profesi (konstanta) besarannya adalah 3,926 dan setiap perubahan/peningkatan variabel tanggung jawab profesi akan menentukan efektivitas kinerja guru. Hal Ini berarti setiap ada kenaikan satu poin pada variabel tanggung jawab profesi akan berakibat naiknya skor variabel efektivitas kinerja guru sebesar 1,619.

Nilai t-hitung $=79,386$ dengan signifikan t sebesar 0,000. Oleh karena itu, hipotesis yang berbunyi terdapat pengaruh positif tanggung jawab profesi terhadap 
efektivitas kinerja guru Madrasah Tsanawiyah di Kota Makassar diterima. Hal ini membuktikan bahwa ada pengaruh yang signifikan tanggung jawab profesi terhadap efektivitas kinerja guru pada Madrasah Tsanawiyah di Kota Makassar. Besarnya pengaruh tanggung jawab profesi terhadap efektivitas kinerja guru pada Madrasah Tsanawiyah di Kota Makassar dapat dilihat pada Tabel 8.

Tabel 8. menunjukkan besar pengaruhnya tanggung jawab profesi terhadap efektivitas kinerja guru $\left(R^{2}\right)$ yaitu sebesar 0.954. $R$ Square $\left(R^{2}\right)$ dapat disebut koefisien determinasi yang dalam hal ini berarti besarnya varian efektivitas kinerja guru yang dipengaruhi atau ditentukan oleh tanggung jawab profesi sebesar 95,40\%. Kekuatan hubungan antara tanggung jawab profesi dengan efektivitas kinerja guru dinyatakan dengan koefisien korelasi $(r)$ sebesar 0,977 dengan $p$ value $=0.000$. Sehingga dapat disimpulkan bahwa hipotesis nol $\left(H_{0}\right)$ ditolak dan hipotesis penelitian yang menyatakan ada pengaruh positif dan signifikan tanggung jawab profesi terhadap efektivitas kinerja guru dapat diterima kebenarannya.

Tabel 8. Nilai Koefisien Determinasi Efektivitas Kinerja Guru atas Tanggung Jawab Profesi

\begin{tabular}{l|r|r|r|r}
\hline \multicolumn{5}{|c}{ Model Summary } \\
\hline Model & $R$ & $R$ Square & Adjusted $R$ Square & $\begin{array}{c}\text { Std. Error of the } \\
\text { Estimate }\end{array}$ \\
\hline 1 & $0,977^{\text {a }}$ & 0,954 & 0,954 & 3,26790
\end{tabular}

a. Predictors: (Constant), Tanggung Jawab Profesi

Sumber: Hasil analisis data, 2021

Pengaruh Komitmen Mengajar terhadap Efektivitas Kinerja Guru pada Madrasah Tsanawiyah di Kota Makassar

Hasil analisis data menggunakan analisis regresi linear sederhana pada variabel komitmen mengajar terhadap efektivitas kinerja guru pada Madrasah Tsanawiyah di Kota Makassar terlihat pada Tabel 9.

Tabel 9. Persamaan Regresi Pengaruh Komitmen Mengajar terhadap Efektivitas Kinerja Guru

\begin{tabular}{|c|c|c|c|c|c|}
\hline \multicolumn{6}{|c|}{ Coefficients } \\
\hline \multirow[b]{2}{*}{ Model } & \multicolumn{2}{|c|}{$\begin{array}{l}\text { Unstandardized } \\
\text { Coefficients }\end{array}$} & $\begin{array}{c}\text { Standardized } \\
\text { Coefficients }\end{array}$ & \multirow[b]{2}{*}{$t$} & \multirow[b]{2}{*}{ Sig. } \\
\hline & B & Std. Error & Beta & & \\
\hline $1 \quad$ (Constant) & 6,200 & 1,261 & & 4,915 & 0,000 \\
\hline Komitmen Mengajar & 1,367 & 0,016 & 0,981 & 87,414 & 0,000 \\
\hline
\end{tabular}

a. Dependent Variable: Efektivitas Kinerja

Sumber: Hasil analisis data, 2021 
Tabel 9 menunjukkan bahwa koefisien regresi diperoleh koefisien arah regresi b sebesar 1,367 dan konstanta a sebesar 6,200. Dengan demikian, bentuk hubungan antara kedua variabel tersebut dapat dinyatakan oleh persamaan regresi: $\hat{Y}=6,200+1,367 \mathrm{X}$. Berdasarkan hasil perhitungan ditemukan efektivitas kinerja guru tanpa komitmen mengajar (konstanta) besarannya adalah 6,200 dan setiap kenaikan atau perubahan variabel komitmen mengajar akan menentukan efektivitas kinerja guru, hal ini dapat dipahami setiap ada kenaikan satu poin pada variabel komitmen mengajar akan berakibat naiknya skor variabel efektivitas kinerja guru sebesar 1,367.

Nilai t-hitung $=87,414$ dengan signifikan t sebesar 0,000. Oleh karena itu, hipotesis yang berbunyi terdapat pengaruh positif komitmen mengajar terhadap efektivitas kinerja guru pada Madrasah Tsanawiyah di Kota Makassar diterima. Hal ini membuktikan bahwa ada pengaruh yang signifikan komitmen mengajar terhadap efektivitas kinerja guru pada Madrasah Tsanawiyah di Kota Makassar. Besarnya pengaruh komitmen mengajar terhadap efektivitas kinerja guru pada Madrasah Tsanawiyah di Kota Makassar dapat dilihat pada Tabel 10.

Tabel 10. Nilai Koefisien Determinasi Efektivitas Kinerja Guru atas Komitmen Mengajar

\begin{tabular}{l|r|r|r|r}
\hline \multicolumn{5}{|c|}{ Model Summary } \\
\hline Model & $R$ & $R$ Square & Adjusted R Square & $\begin{array}{c}\text { Std. Error of the } \\
\text { Estimate }\end{array}$ \\
\hline 1 & 0,981 & 0,962 & 0,962 & 2,97973 \\
\hline
\end{tabular}

a. Predictors: (Constant), Komitmen Mengajar

Sumber: Hasil analisis data, 2021

Tabel 10 menunjukkan besar pengaruhnya $\left(R^{2}\right)$ yaitu sebesar 0.962 . $R$ Square $\left(R^{2}\right)$ dapat disebut koefisien determinasi yang dalam hal ini berarti besarnya varian efektivitas kinerja guru yang dipengaruhi atau ditentukan komitmen mengajar sebesar 96,20\%. Kekuatan hubungan antara komitmen mengajar dengan efektivitas kinerja guru dinyatakan dengan koefisien korelasi $(r$ ) sebesar 0,981 dengan $\mathrm{p}$ value $=0.000$. Hal ini menunjukkan bahwa hipotesis nol $\left(\mathrm{H}_{0}\right)$ ditolak, yang berarti hipotesis penelitian yang menyatakan ada pengaruh positif dan signifikan komitmen mengajar terhadap efektivitas kinerja guru dapat diterima kebenarannya.

\section{Pengaruh Motivasi terhadap Efektivitas Kinerja Guru pada Madrasah Tsanawiyah di Kota Makassar}

Hasil analisis data menggunakan analisis regresi linear sederhana pada variabel motivasi terhadap efektivitas kinerja guru pada Madrasah Tsanawiyah di Kota Makassar terlihat pada Tabel 11. 
Tabel 11. Persamaan Regresi Pengaruh Motivasi terhadap Efektivitas Kinerja Guru

\begin{tabular}{|c|c|c|c|c|c|c|}
\hline \multicolumn{7}{|c|}{ Coefficients } \\
\hline & \multirow[t]{2}{*}{ Model } & \multicolumn{2}{|c|}{$\begin{array}{l}\text { Unstandardized } \\
\text { Coefficients }\end{array}$} & \multirow{2}{*}{$\begin{array}{c}\begin{array}{c}\text { Standardized } \\
\text { Coefficients }\end{array} \\
\text { Beta }\end{array}$} & \multirow[b]{2}{*}{$t$} & \multirow[b]{2}{*}{ Sig. } \\
\hline & & $B$ & Std. Error & & & \\
\hline & (Constant) & 1,422 & 0,741 & & 1,919 & 0,056 \\
\hline & Motivasi & 1,316 & 0,009 & 0,993 & 142,451 & 0,000 \\
\hline
\end{tabular}

a. Dependent Variable: Efektivitas Kinerja,

Sumber: Hasil analisis data, 2021

Tabel 11 menunjukkan koefisien regresi diperoleh koefisien arah regresi b sebesar 1,316 dan konstanta a sebesar 1,422. Dengan demikian bentuk hubungan antara kedua variabel tersebut dapat dinyatakan oleh persamaan regresi: $\hat{Y}=1,422+1,316 \mathrm{X}$. Dari hasil perhitungan ditemukan efektivitas kinerja guru tanpa motivasi (konstanta) besarannya adalah 1,422 dan setiap perubahan/peningkatan variabel motivasi akan menentukan efektivitas kinerja guru. Hal ini berarti setiap ada kenaikan satu poin pada variabel motivasi akan berakibat naiknya skor variabel efektivitas kinerja guru sebesar 1,316.

Nilai t-hitung sebesar 142,451 dengan signifikan t sebesar 0,000. Oleh karena itu, hipotesis yang berbunyi terdapat pengaruh positif motivasi terhadap efektivitas kinerja guru pada Madrasah Tsanawiyah di Kota Makassar diterima. Hal ini membuktikan bahwa ada pengaruh yang signifikan motivasi terhadap efektivitas kinerja guru pada Madrasah Tsanawiyah di Kota Makassar. Besarnya pengaruh motivasi terhadap efektivitas kinerja guru pada Madrasah Tsanawiyah di Kota Makassar dapat dilihat pada Tabel 12.

Tabel 12. Nilai Koefisien Determinasi Efektivitas Kinerja Guru atas Motivasi

\begin{tabular}{l|r|r|r|r}
\hline \multicolumn{5}{c}{ Model Summary } \\
\hline Model & $R$ & $R$ Square & Adjusted $R$ Square & $\begin{array}{c}\text { Std. Error of the } \\
\text { Estimate }\end{array}$ \\
\hline 1 & 0,993 & 0,985 & 0,985 & 1,85056 \\
\hline
\end{tabular}

a. Predictors: (Constant), Motivasi

Sumber: Hasil analisis data, 2021

Tabel 12 menunjukkan besar pengaruhnya $\left(R^{2}\right)$ yaitu sebesar 0.985 . $R$ Square $\left(R^{2}\right)$ dapat disebut koefisien determinasi yang dalam hal ini berarti besarnya varian efektivitas kinerja guru yang dipengaruhi atau ditentukan motivasi sebesar 98,50\% Kekuatan hubungan antara motivasi dengan efektivitas kinerja guru dinyatakan dengan koefisien korelasi $(r)$ sebesar 0,993 dengan $p$ value $=0.000$. Hal ini menunjukkan bahwa hipotesis nol $\left(\mathrm{H}_{0}\right)$ ditolak, yang berarti hipotesis penelitian yang menyatakan ada pengaruh positif dan signifikan motivasi terhadap efektivitas kinerja guru dapat diterima kebenarannya. 
Pengaruh Kepuasan Kerja terhadap Efektivitas Kinerja Guru pada Madrasah Tsanawiyah di Kota Makassar

Hasil analisis data menggunakan analisis regresi linear sederhana pada variabel kepuasan kerja terhadap efektivitas kinerja guru pada Madrasah Tsanawiyah di Kota Makassar terlihat pada Tabel 13.

Tabel 13 menunjukkan koefisien regresi diperoleh koefisien arah regresi b sebesar 1,184 dan konstanta a sebesar 0,104. Dengan demikian, bentuk hubungan antara kedua variabel tersebut dapat dinyatakan oleh persamaan regresi: $\hat{Y}=0,104+1,184 \mathrm{X}$. Dari hasil perhitungan ditemukan efektivitas kinerja guru tanpa kepuasan kerja (konstanta) besarannya adalah 0,104 dan setiap perubahan/peningkatan variabel kepuasan kerja akan menentukan efektivitas kinerja guru. Hal ini berarti setiap ada kenaikan satu poin pada variabel kepuasan kerja akan berakibat naiknya skor variabel efektivitas kinerja guru sebesar 1,184.

Tabel 13. Persamaan Regresi Pengaruh Kepuasan Kerja terhadap Efektivitas Kinerja Guru

Coefficients

\begin{tabular}{|c|c|c|c|c|c|}
\hline \multirow[b]{2}{*}{ Model } & \multicolumn{2}{|c|}{$\begin{array}{l}\text { Unstandardized } \\
\text { Coefficients }\end{array}$} & \multirow{2}{*}{\begin{tabular}{|c|}
$\begin{array}{c}\text { Standardized } \\
\text { Coefficients }\end{array}$ \\
Beta \\
\end{tabular}} & \multirow[b]{2}{*}{$t$} & \multirow[b]{2}{*}{ Sig. } \\
\hline & B & Std. Error & & & \\
\hline (Constant) & 0,104 & 1,528 & & 0,068 & 0,946 \\
\hline Kepuasan Kerja & 1,184 & 0,017 & 0,969 & 68,178 & 0,000 \\
\hline
\end{tabular}

a. Dependent Variable: Efektivitas Kinerja

Sumber: Hasil analisis data, 2021

Nilai t-hitung $=68,178$ dengan signifikan t sebesar 0,000. Oleh karena itu, hipotesis yang terdapat pengaruh positif kepuasan kerja terhadap efektivitas kinerja guru pada Madrasah Tsanawiyah di Kota Makassar diterima. Hal ini membuktikan bahwa ada pengaruh yang signifikan kepuasan kerja terhadap efektivitas kinerja guru pada Madrasah Tsanawiyah di Kota Makassar. Besarnya pengaruh kepuasan kerja terhadap efektivitas kinerja guru pada Madrasah Tsanawiyah di Kota Makassar dapat dilihat pada Tabel 14.

Tabel 14. Nilai Koefisien Determinasi Efektivitas Kinerja Guru atas Kepuasan Kerja

\begin{tabular}{c|r|r|r|r}
\hline \multicolumn{5}{|c}{ Model Summary } \\
\hline Model & $R$ & $R$ Square & Adjusted $R$ Square & $\begin{array}{c}\text { Std. Error of the } \\
\text { Estimate }\end{array}$ \\
\hline 1 & 0,969 & 0,939 & 0,939 & 3,77452 \\
\hline
\end{tabular}

a. Predictors: (Constant), Kepuasan Kerja

Sumber: Hasil analisis data, 2021

Tabel 14 menunjukkan besar pengaruhnya $\left(R^{2}\right)$ yaitu sebesar 0.939. $R$ square $\left(R^{2}\right)$ dapat disebut koefisien determinasi yang dalam hal ini berarti besarnya varian efektivitas kinerja guru yang dipengaruhi atau ditentukan kepuasan kerja sebesar 
93,90\%. Kekuatan hubungan antara kepuasan kerja dengan efektivitas kinerja guru dinyatakan dengan koefisien korelasi $(r)$ sebesar 0,969 dengan $p$ value $=$ 0.000. Hal ini menunjukkan bahwa hipotesis nol $\left(\mathrm{H}_{\mathrm{O}}\right)$ ditolak, yang berarti hipotesis penelitian yang menyatakan ada pengaruh positif dan signifikan kepuasan kerja terhadap efektivitas kinerja guru dapat diterima kebenarannya.

Pengaruh Tanggung Jawab Profesi, Komitmen Mengajar, Motivasi, dan Kepuasan Kerja secara Bersama-sama terhadap Efektivitas Kinerja Guru pada Madrasah Tsanawiyah di Kota Makassar

Hasil analisis data dengan menggunakan analisis regresi linear berganda pada variabel tanggung jawab profesi, komitmen mengajar, motivasi, dan kepuasan kerja secara bersama-sama terhadap efektivitas kinerja guru pada Madrasah Tsanawiyah di Kota Makassar terlihat pada Tabel 15.

Tabel 15. Persamaan Regresi Berganda Tanggung Jawab Profesi, Komitmen Mengajar, Motivasi Dan Kepuasan Kerja Secara Bersama-Sama Terhadap Efektivitas Kinerja Guru

\begin{tabular}{|c|c|c|c|c|c|c|}
\hline \multicolumn{7}{|c|}{ ANOVAa $^{a}$} \\
\hline \multicolumn{2}{|c|}{ Model } & $\begin{array}{l}\text { Sum of } \\
\text { Squares }\end{array}$ & $d f$ & $\begin{array}{l}\text { Mean } \\
\text { Square }\end{array}$ & $F$ & Sig. \\
\hline \multirow[t]{3}{*}{1} & Regression & 69762,813 & 4 & 17440,703 & 6828,915 & $0,000^{b}$ \\
\hline & Residual & 763,631 & 299 & 2,554 & & \\
\hline & Total & 70526,444 & 303 & & & \\
\hline
\end{tabular}

a. Dependent Variable: Efektivitas Kinerja

b. Predictors: (Constant), Kepuasan Kerja, Motivasi, Tanggung Jawab Profesi, Komitmen Mengajar.

Sumber: Hasil analisis data, 2021

Hasil perhitungan berdasarkan Tabel 15 menunjukkan bahwa dari uji Anova diperoleh $F_{\text {hitung }}$ sebesar 6828,915 dengan tingkat signifikansi $0,000<$ taraf signifikansi 0,05. Artinya, secara statistik data yang digunakan untuk membuktikan bahwa semua variabel bebas (tanggung jawab profesi, komitmen mengajar, motivasi, dan kepuasan kerja) berpengaruh terhadap efektivitas kinerja guru. Atau dengan kata lain, tanggung jawab profesi, komitmen mengajar, motivasi, dan kepuasan kerja secara bersama-sama berpengaruh terhadap efektivitas kinerja guru. Keputusannya adalah menolak hipotesis nol dan menerima hipotesis alternatif. Dengan demikian, tanggung jawab profesi, komitmen mengajar, motivasi, dan kepuasan secara bersama-sama berpengaruh terhadap efektivitas kinerja guru. Besarnya pengaruh kepuasan kerja terhadap efektivitas kinerja guru pada Madrasah Tsanawiyah di Kota Makassar dapat dilihat pada Tabel 16.

Berdasarkan Tabel 16, dapat dikatakan bahwa pengaruh tanggung jawab profesi, komitmen mengajar, motivasi, dan kepuasan kerja secara bersama-sama 
terhadap efektivitas kinerja guru adalah 98,90\% dan sisanya dipengaruhi oleh variable lain selain variabel yang diteliti.

Tabel 16. Nilai Koefisien Determinasi Efektivitas Kinerja Guru atas Tanggung Jawab Profesi, Komitmen Mengajar, Motivasi, dan Kepuasan Kerja secara Bersama-sama

\begin{tabular}{l|l|r|r|r}
\hline \multicolumn{5}{|c}{ Model Summary } \\
\hline Model & $R$ & $R$ Square & Adjusted $R$ Square & $\begin{array}{c}\text { Std. Error of the } \\
\text { Estimate }\end{array}$ \\
\hline 1 & $0,995^{a}$ & 0,989 & 0,989 & 1,59811 \\
\hline
\end{tabular}

a. Predictors: (Constant), Kepuasan Kerja, Motivasi, Tanggung Jawab Profesi, Komitmen Mengajar

Sumber: Hasil analisis data, 2021

Hasil penelitian ini sejalan dengan Saud (2008) yang menyebutkan bahwa ada kaitan antara profesi, profesional, profesionalisme, dan profesionalisasi. Selain itu, penelitian yang dilakukan oleh Hartono (2016) dengan judul "Pengaruh Tanggung Jawab Profesi dan Kualifikasi Akademik Terhadap Peningkatan Kemampuan Guru dalam Pengelolaan Pembelajaran di MTs Negeri se-Kabupaten Tuban". Hal ini sesuai pula dengan pernyataan Marselus (2011) sebagai berikut: "Pengembangan profesional guru adalah proses lewat mana para guru baik sendirisendiri maupun bersama-sama dengan orang lain mengkaji, membaharui, dan memperluas komitmen mereka sebagai pelaku perubahan terhadap moral dari pengajaran; dan lewat mana mereka mengembangkan secara kritis pengetahuan, keterampilan dan intelegensi emosionalnya yang penting bagi perencanaan, pemikiran, dan praktik profesional yang baik dengan anak-anaknya".

Hasil penelitian Sulaiman (2013) tentang "Pengaruh Motivasi Kerja Terhadap Kinerja Guru MTs di Kota Samarinda", menunjukkan bahwa motivasi kerja berpengaruh terhadap kinerja guru MTs di Kota Samarinda. Menurut Ahmad (2018) dalam penelitiannya terhadap 135 orang guru menemukan bahwa, kepuasan kerja, pengalaman kerja dan kualifikasi akademik berpengaruh terhadap kinerja guru MTs di Kabupaten Brebes. Hasil penelitian ini juga sejalan dengan perkataan Usman (2005), "Kinerja merupakan hasil perpaduan dari kecakapan dan motivasi dimana masing-masing variabelnya dihasilkan dari sejumlah faktor lain yang saling mempengaruhi, seperti tanggung jawab profesi, komitmen dalam menjalankan tugas, serta kepuasan dalam bekerja".

Berdasarkan hasil penelitian ini dan berbagai pendapat yang telah dikemukakan, dapat dipahami bahwa seseorang akan bekerja secara professional dan menunjukkan efektivitas kinerjanya jika memiliki kemampuan/kompetensi yang tinggi, memiliki motivasi ekstrinsik dan intrinsik yang baik, memiliki komitmen dalam menjalankan tugasnya, serta memiliki kepuasan kerja yang tinggi pula. Sebab efektivitas kinerja terwujud berkat kombinasi berbagai factor dari sumber daya manusia. 


\section{PENUTUP/SIMPULAN}

Penelitian ini menunjukkan bahwa efektivitas kinerja guru pada Madrasah Tsanawiyah di Kota Makassar pada umumnya dalam kategori tinggi. Namun demikian, masih ada beberapa responden yang memperoleh skor dalam kategori rendah dan sedang. Hal ini menunjukkan bahwa pada item kinerja guru masih perlu ditingkatkan. Hal yang sama pada variabel komitmen mengajar, motivasi dan kepuasan kerja guru pada Madrasah Tsanawiyah di Kota Makassar pada umumnya responden memperoleh skor dalam kategori tinggi, walaupun masih terdapat beberapa responden memperoleh skor rendah dan sedang. Hal ini menunjukkan bahwa ketiga variabel tersebut masih perlu untuk selalu ditingkatkan.

Tanggung jawab profesi, komitmen mengajar, motivasi, dan kepuasan kerja masing-masing memiliki pengaruh yang signifikan terhadap efektivitas kinerja guru pada Madrasah Tsanawiyah di Kota Makassar. Tanggung jawab profesi, komitmen mengajar, motivasi, dan kepuasan kerja, secara bersama-sama berpengaruh positif dan signifikan terhadap efektivitas kinerja guru pada Madrasah Tsanawiyah di kota Makassar.

Penelitian ini diharapkan dapat memberikan implikasi kepada kepala sekolah dan pengambil kebijakan pendidikan di jenjang Madrasah Tsanawiyah hendaknya memperhatikan peningkatan tanggung jawab profesi, komitmen mengajar, motivasi dan kepuasan kerja guru. Hal tersebut terbukti berpengaruh, baik secara sendirisendiri maupun secara bersama-sama terhadap efektivitas kinerja guru Madrasah Tsanawiyah, Termasuk pada indicator-indikator yang masih rendah dan sedang perlu mendapat penanganan agar kinerja guru semakin baik. Selain itu, kepada peneliti diharapkan dapat mengembangkan hasil penelitian ini dengan melakukan kajian yang luas terhadap faktor-faktor yang memengaruhi kepuasan kerja, komitmen mengajar, motivasi, kepuasan kerja dan efektivitas kinerja guru. Kajian yang luas dapat dilakukan dengan mengembangkan variabel dalam penelitian ini serta lokus penelitian.

\section{DAFTAR PUSTAKA}

Ahmad, N. A. (2018). Pengaruh Kepuasan Kerja, Pengalaman Kerja, dan Kualifikasi Akademik terhadap Kinerja Guru MTs di Kabupaten Brebes. Jurnal Pendidikan Dasar Islam, 2(3), 11-22.

Boyd, R. T. C. (2002). Improving Teacher Evaluations. Practical Assessment, Research and Evaluation, 1(7), 8-11. https://doi.org/https://doi.org/10.7275/07f7-hf08

Bukhari, U. (2010). IImu Pendidikan Islam. Jakarta: Amzah.

Danial, Damopolii, M., \& Syamsudduha, S. (2019). Hubungan Antara Budaya Madrasah dengan Motivasi Kerja Guru di MTs se-Kecamatan Sinjai Barat. 
https://doi.org/doi.org/10.24252/Ip.2019v22n1i12

Hartono, H. (2016). Pengaruh Tanggung Jawab Profesi dan Kualifikasi Akademik terhadap Peningkatan Kemampuan Guru dalam Pengelolaan Pembelajaran di MTs Negeri Se-Kabupaten Tuban. Jurnal Pendidikan Unimuda, 4(3), 237 248.

Maselus, R. P. (2011). Sertifikasi Profesi Guru; Konsep Dasar, Problematika, dan Implementasinya. Jakarta: Indeks Permata Puri Media.

Rahman, D., \& Husain, A. (2020). Motivasi Kerja Guru: Hubungan Realitas Iklim dan Budaya dengan Motivasi Kerja Guru Madrasah. Sidoarjo: Nizamia Learning Center.

Saud, U. S. (2008). Pengembangan Profesi Guru. Bandung: Alfabeta.

Sukamto, P. Y. (2016). Pengaruh Kompetensi Guru, Komitmen Kerja dan Motivasi Kerja terhadap Kinerja Guru SMP Andalan di Sleman. Jurnal Penelitian IImu Pendidikan, 9(2).

Sulaiman, A. (2013). Pengaruh Motivasi Kerja terhadap Kinerja Guru MTs di Kota Samarinda. Jurnal Al-Hikmah, 9(3), 368-378.

Tafqihan, Z., \& Suryanto, S. (2014). Pengaruh Kompetensi Guru terhadap Komitmen Profesional dan Dampaknya pada Kinerja Serta Kepuasan Kerja Guru Matematika SMP dan MTs. Jurnal Riset Pendidikan Matematika, 1(2), 285. https://doi.org/10.21831/jrpm.v1i2.2682

Usman, M. U. (2005). Menjadi Guru Professional. Bandung: Remaja Rosdakarya.

Zangaro, G. (2001). Organizational commitment: A Concept Analysis. Nursing Forum, 36(2). 